\title{
Microbiological safety of commonly available eye ointments and their in-vitro anti-bacterial potency
}

\author{
Mrityunjoy Acharjee ${ }^{1}$, Rakhi Baishnaib ${ }^{1}$, Rashed Noor ${ }^{2, *}$ \\ ${ }^{1}$ Department of Microbiology, Stamford University Bangladesh, 51 Siddeswari Road, Dhaka-1217 \\ ${ }^{2}$ School of Life Sciences (SLS), Independent University, Bangladesh (IUB), Plot 16, Block B, Aftabuddin Ahmed Road, Bashundhara, Dhaka 1229, Bangladesh \\ Dhaka 1229, Bangladesh
}

\begin{abstract}
Current study attempted to check out the microbiological quality of some common sterile ointment commonly implemented for the treatment of eye infections in Bangladesh. Seventeen (17) different eye ointment (T-Mycin, Aprocin, Bactin, Optimox and Cloram, Hypomer gel, Sonexa, Polytracin, Cero, Aristobet, Lotepred, Herpigel, Gentob, Xoviral, Zirgan, Xovir, Tomycin, Tobirax, AFm-plus and Parafresh) were microbiologically examined through common and traditional cultural methods. Total viable bacterial and fungal contamination was found up to $10^{6}$ and $10^{5} \mathrm{cfu} / \mathrm{ml}$ respectively. Among the 17 samples T-Mycin, Aprocin, Sonexa, Polytracinand Tomycinwere free from fungal contamination. All the samples significantly exceeded United States Pharmacopeia (USP) or British Pharmacopeia (BP) limit $\left(<\mathbf{1 0 ^ { 2 }} \mathbf{~} \mathbf{~ f u} / \mathbf{m l}\right)$ in case of Total viable bacteria and fungus contamination. While the coliforms (Escherichia coli and Klebsheilla spp.) were absent in all samples, the prevalence of Staphylococcus spp. was $100 \%$ in all samples up to $10^{3}$ while the Bacillus spp. was found up to $10^{2} \mathrm{cfu} / \mathrm{ml}$. Pseudomonas spp. was cultivated in TMycin, Aprocin Hypomer gel, Sonexa, Polytracin, Cero, Aristobet and Lotepred up to $10^{3} \mathrm{cfu} / \mathrm{ml}$. All the 5 drugs showed their antibacterial potency with satisfactory range of zone diameter againstE. coli, Pseudomonas spp., Staphylococcus spp., Klebsheilla spp. and Bacillus spp. In case of all 17 ointments the average zone diameter range was noticed within $13 \mathrm{~mm}-22 \mathrm{~mm}$. The highest zone diameter $(22 \mathrm{~mm})$ was recorded against $E$. coli produced by Aprocin and minimum zone diameter $(13 \mathrm{~mm})$ was recorded against Bacillus spp. produced by Bactin, Optimox and Cloram.Gentamicin and Streptomycin were used as positive control against the tested bacteria.
\end{abstract}

\section{Introduction}

The extensive existence of microbial agent in the pharmaceutical products may hinder to prove its antimicrobial potency ${ }^{1-3}$. Due to several inconsistency in the good manufacturing practice (GMP), poor quality of raw materials and manufacturing water, lack of microbiological monitoring of the equipments and unhygienic environment, packaging defect and inappropriate storage condition are the major causes of microbial spoilage in the pharmaceutical products ${ }^{4-7}$. Some common microflora like Clostridium tetani, Pseudomonasaeruginosa, fungi and viruses may generate the spoilage of the final products $2,8-13$.

According to the USP and BP guidelines the presence of contaminating total viable bacteria exceeding the acceptable limit of $<102 \mathrm{cfu} / \mathrm{g}$ especially in sterile drugs such as eye drops and ointment brings a major threat for consumer ${ }^{14-24}$. One of the studies reflected the presence of microbial contamination in the finished products as a result of the market objection ${ }^{12,19,25,26}$. As described in early study, several diseases have been noticed in Bangladeshi community due to the microbiological spoilage in different pharmaceutical drugs $21,27,28-32$. Huge bacterial and fungal contamination was observed in sterile liquid drugs those were commonly used to treat eye and ear infection ${ }^{33}$.Furthermore, the increasing rate of drug resistant bacteria as well as the reduction of drug potency may recommend the necessity to sort out the antibacterial traits of the pharmaceutical drug ${ }^{34-38}$. However, the quality control and quality assurance department should take necessary action to eradicate the growth of objectionable microbes and execute the proper microbiological monitoring system following by GMP and HACCP guidelines. Considering all the things, the present study (1) assessed the bacterial and fungal load of the topical products commonly used to eradicate eye related complications along with their antibacterial activity.

\section{Materials amd Methods}

Sample Collection, Processing, and Microbiological Analysis

Seventeen (17) different eye ointment samples (T-Mycin, Aprocin, Bactin, Optimox, Cloram, Hypomer gel, Sonexa, Polytracin, Cero, Aristobet, Lotepred, Herpigel, Gentob, Xoviral, Zirgan, Xovir, Tomycin, Tobirax, AFm-plus and Parafresh) labeled with manufacturing and expiry dates were collected from different retailer drug stores located within the city of Dhaka and were subjected to microbiological examinations; i.e., the total viable bacteria and fungi were quantified and the presence of specific pathogens was detected as well ${ }^{39,40}$. Briefly, $10 \mathrm{ml}$ of

*Corresponding author:

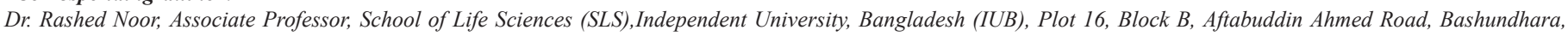
Dhaka 1229, Bangladesh. E-mail: noor.rashed@yahoo.com 
samples were homogenized with $90 \mathrm{ml}$ of buffer peptone water (BPW) and serial dilutions were prepared up to 10-4. An aliquot of $0.1 \mathrm{ml}$ of each suspension from the $10^{-2}$ was spread onto Nutrient agar (NA) plate to enumerate the total bacteria (TVB) and on Sabouraud dextrose agar (SDA) plate for the estimation of fungal load. The NA and SDA plates were incubated at $37^{\circ} \mathrm{C}$ for 24 hours and at $25^{\circ} \mathrm{C}$ for 24 to 48 hours, respectively ${ }^{40}$.

\section{Detection of Specific Pathogenic Bacteria}

An aliquot of $0.1 \mathrm{ml}$ from the 10-2 dilution of each sample was spread onto Mac Conkey agar, Mannitol salt agar (MSA), Pseudomonas agar, and Mannitol egg yolk polymyxin (MYP) agar base media for the enumeration of Escherichia coli, Klebsheilla spp. Staphylococcus spp., Pseudomonas spp., and Bacillus spp. consecutively. All the plates were incubated at $37^{\circ}$ $\mathrm{C}$ for 24 hours except MFC agar which was incubated at $45^{\circ} \mathrm{C}$ for 18-24 hours. Confirmative identification of the specific pathogens was accomplished through the biochemical tests ${ }^{39,40}$.

Determination of antibacterial activity of eye ointment against the laboratory stock culture

To examine the drug efficacy of T-Mycin, Aprocin, Bactin, Optimox, Cloram, Hypomer gel, Sonexa, Polytracin, Cero, Aristobet, Lotepred, Herpigel, Gentob, Xoviral, Zirgan, Xovir, Tomycin, Tobirax, AFm-plus and Parafreshagainst different tested bacteriaisolated from the different sources: this study was introduced agar well difusion methods on Muller Hington Agar $^{39}$. According to the suggested method by Clinical and Standared Laboratory Institute; a loopfull culture of the tested bacteria (Escherichia coli, Klebsiella spp., Pseudomonas spp., Staphylococcus spp and Bacillus spp.) was inoculated into the appropriately labeled sterile tubes containing Mueller Hinton $(\mathrm{MH})$ broth (Oxoid Ltd, England) and the bacterial lawn was prepared onto the surface of the MHA media. Then wells $(8 \mathrm{~mm})$ were made on the inoculated MHA media and $1001 / 4 \mathrm{~L}$ antibiotic solution was added in to the wells along with a positive control antibiotic disc (Gentamicin, $101 / 4 \mathrm{~g}$ ) and a negative control (normal saline). After incubation at $37{ }^{\circ} \mathrm{C}$ for 24 hours the presence of clear zone around the sample solution (if any) was analytical for the existence of the antibacterial activity of the samples tested ${ }^{39}$.

\section{Results \& Discussions}

In Bangladesh Pharmaceutical sectors has huge contribution to earn foreign revenue ${ }^{10}$. One of our Previous research group discussed the effective in-process microbiological quality controlmay reduce the proliferation of microbial agent during manufacturing, packaging, distribution and storage as well as examine the quality measurement of both raw materials and finished product ${ }^{12,19,25,26}$.

\section{Prevalence of Microorganisms in Eye Ointments}

In this study all the eye ointment revealed a huge aerobic bacterial and fungal prevalence up to $10^{6}$ and $10^{5} \mathrm{cfu} / \mathrm{ml}$ respectively
(Table 1). The total viable bacterial and fungal load was found to be exceeded the USP limit $\left(<10^{2} \mathrm{cfu} / \mathrm{g}\right)$ in all the samples. Among the 17 samples only 5 samples were found free from fungal contamination. In case of T-Mycin, the propagation of Pseudomonas spp., Staphylococcus spp. and Bacillus spp. were quantified $2.3 \times 10^{2}, 2.8 \times 10^{3}$ and $2.3 \times 10^{2} \mathrm{cfu} / \mathrm{ml}$ consecutively. Pseudomonas spp., Staphylococcus spp. and Bacillus spp. were found up to $10^{3} \mathrm{cfu} / \mathrm{ml}$ for Aprocin while only Staphylococcus spp was found up to $10^{2} \mathrm{cfu} / \mathrm{ml}$ in Bactin, Optimox and Cloram. In Hypomer gel, Sonexa, Polytracin, Cero, Aristobet and Lotepred the load of Pseudomonas spp., Staphylococcus spp. and Bacillus spp. were observed up tp $10^{4} \mathrm{cfu} / \mathrm{ml}$. Staphylococcus spp. and Bacillus spp were found in Herpigel, Gentob, Xoviral up to $10^{3}$ cfu/ml. Only Staphylococcus spp. was cultivated in Zirgan, Xovir, Tomycin, Tobirax, AFm-plus and Parafresh up to $10^{3} \mathrm{cfu} / \mathrm{ml}$. E. coli and Klebsheilla spp. were totally absent in all the samples (Table 1). However, the bio-burden was assessed out of the acceptable limits recommended by USP or BP ${ }^{39-44}$.Thus $80 \%$ of the samples studied were found to be microbiologically uncontrolled in case total viable and fungus contamination while the coliform was absent in every case. Among the specific pathogenic bacteria, the presence of Staphylococcus spp. was prominent (Table 1).

\section{Detection of antibacterial activity of EyeOintments}

The potency of 17 eye ointment against different tested bacteria (Escherichia coli, Klebsiella spp., Pseudomonas spp., Staphylococcus spp and Bacillus spp) was determined by observing the zone diameter through agar well diffusion method. Most of drugs showed their antibacterial potency with satisfactory range of zone diameter againstall the tested bacteria. In case of T-Mycin the zone was recorded $20 \mathrm{~mm}, 17 \mathrm{~mm} 18 \mathrm{~mm}, 15 \mathrm{~mm}$ and $13 \mathrm{~mm}$ against E. coli, Pseudomonas spp., Staphylococcus spp., Klebsiella spp and Bacillus spp consecutively. Aprocin showed $22 \mathrm{~mm}, 18 \mathrm{~mm}, 15 \mathrm{~mm}, 17 \mathrm{~mm}$ and $15 \mathrm{~mm}$ of zone diameter for $E$. coli, Pseudomonas spp., Staphylococcus spp., Klebsiella spp and Bacillus spp consecutively. Bactin showed $18 \mathrm{~mm}, 15 \mathrm{~mm}, 15 \mathrm{~mm}$, $17 \mathrm{~mm}, 13 \mathrm{~mm}$ of zone diameter for E. coli, Pseudomonas spp., Staphylococcus spp., Klebsiella spp and Bacillus sppconsecutively. Optimoxshowed $18 \mathrm{~mm}, 17 \mathrm{~mm}, 18 \mathrm{~mm}, 16 \mathrm{~mm}$ and $13 \mathrm{~mm}$ of zone diameter against E. coli, Pseudomonas spp., Staphylococcus spp., Klebsiella spp and Bacillus sppconsecutively. While the zone diameter was found $20 \mathrm{~mm}$, $17 \mathrm{~mm}, 18 \mathrm{~mm}, 15 \mathrm{~mm}$ and $13 \mathrm{~mm}$ against E. coli, Pseudomonas spp., Staphylococcus spp., Klebsiella spp and Bacillus spp.consecutively. Hypomer gel showed its potency $20 \mathrm{~mm}$ for E. coli and Klebsiella spp.(Table 2). Sonexa exhibited zone diameter $20 \mathrm{~mm}$ and $19 \mathrm{~mm}$ for E. coli and Klebsiella spp. while Polytracin showed $17 \mathrm{~mm}, 17 \mathrm{~mm}, 18 \mathrm{~mm}$ and $17 \mathrm{~mm}$ against $E$. coli, Pseudomonas spp., Klebsiella spp and Bacillus spp. Cero showed antibacterial potency $18 \mathrm{~mm}, 17 \mathrm{~mm}, 17 \mathrm{~mm}$ and $15 \mathrm{~mm}$ against E. coli, Pseudomonas spp., Klebsiella spp and Bacillus spp. $18 \mathrm{~mm}, 18 \mathrm{~mm}, 17 \mathrm{~mm}$ and $15 \mathrm{~mm}$ zone were produced by 
Table 1: Prevalence of pathogenic microorganisms in eye ointment

\begin{tabular}{|c|c|c|c|c|c|c|c|}
\hline Name of Samples & TVB & Fungi & E. coli & $\begin{array}{l}\text { Pseudomonas } \\
\text { spp. }\end{array}$ & $\begin{array}{c}\text { Staphylococcus } \\
\text { aureus. }\end{array}$ & $\begin{array}{c}\text { Klebsheilla } \\
\text { spp. }\end{array}$ & $\begin{array}{c}\text { Bacillus } \\
\text { spp. }\end{array}$ \\
\hline T-Mycin $(n=5)$ & $2.0 \times 10^{6}$ & 0 & 0 & $2.3 \times 10^{2}$ & $2.8 \times 10^{3}$ & 0 & $2.3 \times 10^{2}$ \\
\hline $\operatorname{Bactin}(n=5)$ & $7.5 \times 10^{6}$ & $7.5 \times 10^{5}$ & 0 & 0 & $7.0 \times 10^{2}$ & 0 & 0 \\
\hline Optimox $(n=5)$ & $2.5 \times 10^{5}$ & $2.5 \times 10^{4}$ & 0 & 0 & $2.9 \times 10^{2}$ & 0 & 0 \\
\hline Cloram $(n=5)$ & $4.5 \times 10^{5}$ & $4.5 \times 10^{4}$ & 0 & 0 & $4.7 \times 10^{2}$ & 0 & 0 \\
\hline Sonexa & $1.0 \times 10^{3}$ & 0 & 0 & $4.5 \times 10^{3}$ & $4.3 \times 10^{3}$ & 0 & $4.7 \times 10^{4}$ \\
\hline Polytracin & $1.6 \times 10^{4}$ & 0 & 0 & $3.7 \times 10^{4}$ & $7.0 \times 10^{5}$ & 0 & $5.7 \times 10^{3}$ \\
\hline Cero & $3.3 \times 10^{2}$ & $1.1 \times 10^{3}$ & 0 & $2.0 \times 10^{3}$ & $2.9 \times 10^{3}$ & 0 & $2.0 \times 10^{3}$ \\
\hline Aristobet & $2.2 \times 10^{36}$ & $4.7 \times 10^{4}$ & 0 & $4.5 \times 10^{3}$ & $4.7 \times 10^{3}$ & 0 & $4.4 \times 10^{3}$ \\
\hline Lotepred & $1.0 \times 10^{3}$ & $5.7 \times 10^{3}$ & 0 & $6.7 \times 10^{4}$ & $3.5 \times 10^{3}$ & 0 & $6.0 \times 10^{3}$ \\
\hline Xovir & $1.5 \times 10^{5}$ & $2.0 \times 10^{4}$ & 0 & 0 & $2.8 \times 10^{3}$ & 0 & 0 \\
\hline Tomycin & $4.5 \times 10^{4}$ & 0 & 0 & 0 & $4.3 \times 10^{3}$ & 0 & 0 \\
\hline Tobirax & $2.0 \times 10^{5}$ & $2.5 \times 10^{4}$ & 0 & 0 & $7.0 \times 10^{3}$ & 0 & 0 \\
\hline AFm-plus & $2.8 \times 10^{4}$ & $1.7 \times 10^{3}$ & 0 & 0 & $2.9 \times 10^{3}$ & 0 & 0 \\
\hline Parafresh & $4.0 \times 10^{5}$ & $3.7 \times 10^{4}$ & 0 & 0 & $4.7 \times 10^{3}$ & 0 & 0 \\
\hline
\end{tabular}

All the experiments were performed in triplicates and the results were reproducible.

USP Limit:

Total viable bacteria $<10^{2} \mathrm{cfu} / \mathrm{g}$

Total fungal load $<10^{1} \mathrm{cfu} / \mathrm{g}$.

Table 2: Detection of antibacterial activity of eye ointment against laboratory strain.

\begin{tabular}{|c|c|c|c|c|c|}
\hline \multirow[b]{2}{*}{ Name ofSamples } & \multicolumn{5}{|c|}{ Zone diameter $(\mathrm{mm})$} \\
\hline & E. coli & Pseudomonas spp. & Staphylococcus aureus. & Klebsheilla spp. & Bacillus spp. \\
\hline T-Mycin $(n=5)$ & 20 & 17 & 18 & 15 & 13 \\
\hline $\operatorname{Aprocin}(n=5)$ & 22 & 18 & 15 & 17 & 15 \\
\hline $\operatorname{Bactin}(n=5)$ & 18 & 15 & 15 & 17 & 13 \\
\hline Optimox $(n=5)$ & 18 & 17 & 18 & 16 & 13 \\
\hline Cloram $(n=5)$ & 20 & 17 & 18 & 15 & 13 \\
\hline Hypomer gel & 20 & 0 & 0 & 20 & 0 \\
\hline Sonexa & 20 & 0 & 0 & 19 & 0 \\
\hline Polytracin & 17 & 17 & 0 & 18 & 17 \\
\hline Cero & 18 & 17 & 0 & 17 & 15 \\
\hline Aristobet & 18 & 18 & 0 & 17 & 15 \\
\hline Lotepred & 20 & 17 & 0 & 16 & 18 \\
\hline Herpigel & 18 & 15 & 0 & 17 & 18 \\
\hline Gentob & 15 & 0 & 0 & 16 & 17 \\
\hline Xoviral & 17 & 0 & 17 & 17 & 17 \\
\hline Zirgan, & 17 & 0 & 17 & 18 & 15 \\
\hline Xovir & 15 & 0 & 18 & 19 & 14 \\
\hline Tomycin & 15 & 15 & 18 & 18 & 14 \\
\hline Tobirax & 18 & 17 & 17 & 18 & 17 \\
\hline AFm-plus & 18 & 17 & 20 & 18 & 16 \\
\hline Parafresh & 17 & 18 & 20 & 17 & 15 \\
\hline \multicolumn{6}{|l|}{ Positive control } \\
\hline Gentamicin & 25 & 22 & 22 & 25 & 20 \\
\hline Streptomycin & 21 & 22 & 20 & 22 & 22 \\
\hline
\end{tabular}

All the experiments were performed in triplicates and the results were reproducible. 
Aristobet against E. coli, Pseudomonas spp., Klebsiella spp and Bacillus spp. Lotepred showed zone diameter $20 \mathrm{~mm}, 17 \mathrm{~mm}$, $16 \mathrm{~mm}$ and $18 \mathrm{~mm}$ for E. coli, Pseudomonas spp., Klebsiella spp and Bacillus spp. Herpigel showed zone diameter $18 \mathrm{~mm}, 15 \mathrm{~mm}$, $17 \mathrm{~mm}$ and $18 \mathrm{~mm}$ for E. coli, Pseudomonas spp., Klebsiella spp and Bacillus spp. Gentob showed antibacterial potency $15 \mathrm{~mm}$, $16 \mathrm{~mm}$ and $17 \mathrm{~mm}$ for E. coli, Klebsiella spp and Bacillus spp. The zone diameter $17 \mathrm{~mm}$ was produced by Xoviral against $E$. coli, Staphylococcus spp., Klebsiella spp and Bacillus spp. Zirgan showed zone diameter $17 \mathrm{~mm}, 17 \mathrm{~mm}, 18 \mathrm{~mm}$ and $15 \mathrm{~mm}$ for $E$. coli, Staphylococcus spp., Klebsiella spp., Bacillus sppand 15mm, $18 \mathrm{~mm}, 19 \mathrm{~mm}, 14 \mathrm{~mm}$ zone were produced by Xovir for E. coli, Staphylococcus spp., Klebsiella spp., Bacillus spp. Tomycin showed $15 \mathrm{~mm}, 15 \mathrm{~mm}, 18 \mathrm{~mm}, 18 \mathrm{~mm}$ and $14 \mathrm{~mm}$ for E. coli, Pseudomonas spp., Staphylococcus spp., Klebsiella spp and Bacillus spp. Tobirax showed $18 \mathrm{~mm}, 17 \mathrm{~mm}, 17 \mathrm{~mm}, 18 \mathrm{~mm}$ and $17 \mathrm{~mm}$ for E. coli, Pseudomonas spp., Staphylococcus spp., Klebsiella spp and Bacillus spp. AFm-plus exhibited 18mm, $17 \mathrm{~mm}, 20 \mathrm{~mm}, 18 \mathrm{~mm}$ and $16 \mathrm{~mm}$ for E. coli, Pseudomonas spp., Staphylococcus spp., Klebsiella spp and Bacillus spp. Parafresh showed antibacterial potency $17 \mathrm{~mm}, 18 \mathrm{~mm}, 20 \mathrm{~mm}, 17 \mathrm{~mm}$ and $15 \mathrm{~mm}$ for E. coli, Pseudomonas spp., Staphylococcus spp., Klebsiella spp and Bacillus spp. (table 1).

\section{Conclusion}

To ensure the consumers health safety as well as increase the product quality of different pharmaceuticals it has no alternative to eradicate the growth of undesirable microbial agent. Day by day disease medication is going to more difficult due to the propagation of spoilage micro-flora more than the marginal limit. During the production period every Good hygiene practices, proper handling, clean environment are necessary for avoiding microbial contamination and maintenance of drug quality. To ensure the patient safety as well as to maintain the public health harmony, a customary microbiological examination of sterile drugs is suggested, especially in the developing countries, where the ease of microbial contamination is usual.

\section{Competing interests}

The authors declare that they have no competing interests.

\section{Acknowledgement}

We thank Microbiology Laboratory, Stamford University Bangladesh for laboratory facilities, technical assistance and financial aid.

\section{References}

1. Coker M. 2005. An assessment of microbial contamination during drug manufacturing in Ibadan, Nigeria. Eur J Sci Res.7:19-23.

2. Mwambete KD, Justin TM and Fazleabbas SF. 2009. Microbiological assessment of commercially available quinine syrups and water for injections in Dares Salaam,Tanzania. Top J Pharm Res. 8 (5): 441-447.

3. Denyer S and Baird R.1990. Guide to Microbiological Control in Pharmaceuticals.1st ed., Chichester \& Ellis Horwood:29-52.
4. Furrer P, Mayer JM, Gurny R. 2002. Ocular tolerance of preservatives and alternatives. Eur J Pharm Biopharm. 53 (2): 63-80.

5. Barkman R, Germanis M, Karpe G.1969. Preservatives in eye drops. Acta Ophthalmol (Copenh).47 (4):461-75.

6. Tasli H, Cosar G. 2001. Microbial contamination of eye drops. Cent Eur $J$ Public Health. 9(3): 162-4.

7. Pisella PJ, Pouliquen P, Baudouin C. 2002. Prevalence of ocular symptoms and signs with preserved and preservative free glaucoma medication. $\mathrm{Br}$ J Ophthalmol. 86 (4):18-23.

8. Schein OD, Hibberd PL, Starck T. 1992. Microbial contamination of inuse ocular medications. Arch Ophthalmol. 110 (8): 2-5.

9. Geyer O, Bottone EJ, Podos SM. 1995. Microbial contamination of medications used to treat glaucoma. Br J Ophthalmol. 79 (37): 6-9.

10. Kallings LO, Ringertz O, Silverstolpe L, Ernerfeldt F. 1996. Microbial contamination of medical preparation. Acta PhamacaSuccica. 3: 219-228.

11. Hugo WB and Russel AD. 1992. Ecology of Microorganism as it Affects the Pharmaceutical Industry (ed). Pharmaceutical Microbiology.5th ed; Blackwell \& Underwood. 353.

12. Clark PJ, Ong B, Stanley CB. 1997. Contamination of diagnostic ophthalmic solutions in primary eye care settings. Mil Med. 162 (50): $1-6$.

13. Kamil, $\mathrm{OH}$ and Lupuliasa D. 2011. Modern aspects regarding the Microbial spoilage of pharmaceutical Products. FARMACIA. 59 (2): 133.

14. United States Pharmacopeia (USP). 2003. Microbiological examination of non-sterile products: Tests for specified microorganisms. Pharm Forum. 29 (5): 1722-1733.

15. Donzis PB, Mondino BJ, Weissman BA. 1987. Microbial contamination of contact lens care systems. Amer J Opthalmol. 104 (3): 25-33.

16. Wilson LA, Schlitzer RL, Ahearn DG. 1981. Pseudomonas corneal ulcers associated with soft contact lens wear. Amer J Opthalmol. 92 (5): 46-54.

17. Parment P, Ronnerstam R. 1981. Soft contact lens keratitis associated with Serratiamarcesens. Acta Ophtalmol. 59 (5): 60-65.

18. Patrinely JR, Wilhelmus KR, Rubin JM.1985. Bacterial keratitis associated with extended wear soft contact lenses. CLAO. 11 (2): 34-36.

19. Mayo MS, Schlitzer RL, Ward MA. 1987. Assocation of Pseudomonas and Serratia corneal ulcers with use of contaminated solutions. J Clin Micro. 25 (1): 398-400.

20. MMWR Morb Mortal Weekly Rep 2006; 55 (56): 3-4.

21. Hovding G, Sjursen H. 1982. Bacterial contamination of drops and dropper tips of in use multi dose eye drop bottles. Acta Ophthalmol. 60 (2): $13-22$.

22. Stevens JD, Matheson MM. 1992. Survey of the contamination of eye drops of hospital inpatients and recommendations for the changing of current practice in eye drop dispensing. Br J Ophthalmol. 76(1): 36-38.

23. Marion AD, Tpert MJ.1986. Bacterial contamination of timolol in use by a non-selected clinic population. Invest Ophthalmol Vis Sci. 36.

24. Geyer O, Bottone EJ, Podos SM, Schumer RA, Asbell PA.1995. Microbial contamination of medications used to treat glaucoma. Br J Ophthalmol. 79(4): $376-379$.

25. Donzis PB. 1997.Corneal ulcer associated with contamination of aerosol saline spray tip. Am J Ophthalmol. 124 (39): 4-5.

26. Brudieu E, Duc DL, Masella JJ. 1999. Bacterial contamination of multidose ocular solutions. A prospective study at the Grenoble Teaching Hospital. Pathol Biol (Paris) 47 (10):1065-70.

27. Perry HD, Donnenfeld ED. 2003. Issues in the use of preservative-free topicals. Manag Care. 12(12): 39-41.

28. Davison AL, Hooper WL, Spooner DF, Farwell JA, Baird R. 1991.The validity of the criteriaof pharmacopoeial preservative efficacy tests a pilot study. Pharm Jf. 246 (55): 5-7.

29. Coad CT, Osato MS, Wilhelmus KR. 1984. Bacterial contamination of eye drop dispensers. Am J Ophthalmol. 98 (5): 48-51. 
30. Preservation of eye-drops. 1964. Pharm J. 192 (58): 7-8.

31. Stewart HL. 1972. Prolonged antibacterial activity of fluoresceinan aesthetic solution. Arch Ophthalmol., 88 (38): 5-7.

32. Dubois SK, Pinney RJ, Davison AL. 1989. Investigation of the levels of bacterial contamination in used eye drops. Poster presentation, British Pharmaceutical Conference, Keele.

33. Alfonso R, Gennaro. 1990. 18th Ed.; Remingtons Pharmaceutical Sciences.

34. Hossain J. 2009. Importance of the bio burden test in pharmaceutical quality control. Pharmaceutical Microbiology Forum., 15(1): 2-14.

35. Moniruzzaman M, Ashrafi MFF, Mia Z. 2012. Qualitative and quantitative microbiological studies of antacid and paraceutamol suspensions from different drugstores of Dhaka. Dhaka Uni J Biolog Sci. 21 (1): 105-107.

36. Hossain MA, Raton KA, Noor R. 2013. Bacteriological study of stool samples collected fromchildren suffering from diarrhea. J Global Biosciences, 2 (5): 160-165.

37. Raton KA, Hossain MA, Noor R. 2013. Multiplex real-time PCR assay for detection of respiratory pathogens among pneumonia affected children. American Journal of Biomedical and Life Sciences., 1(3): 53-57
38. Elizabeth, K.M. 2005. Antimicrobial activity of Terminalia bellerica.Indian J Clin Biochem., 20(2):150-153.

39. Hugo WB and Russel AD.1998. Pharmaceutical Microbiology. 6th ed. Oxford, UK: Blackwell Scientific Publications.

40. Parke MS. 2000. Microbiological contamination and preservation of pharmaceutical preparations. 2nd ed; The science of dosage from design. China \& Churchill Livingstone; 220.

41. Gad GFM, Aly RAI, Ashour MSI. 2011. Microbial Evaluation of Some Non-sterile Pharmaceutical Preparations Commonly Used in the Egyptian Market. Trop. J. Pharm. Res., 10(4): 437-445.

42. Braide W, Nwosu IL, Offor EIU, Popgbara LB, Awurum IN. 2012. Microbial quality of some topical pharmaceutical products sold in abia state, Nigeria. Int J Pharm and Therapeutics., 2 (4): 26-37.

43. Khanom S, Das KK, Banik S, Noor R. 2013. Microbiological analysis of liquid oral drugs available in Bangladesh. Int J Pharm Pharm Sci.5 (4): $479-482$.

44. Dabbah R, Knapp J, Sutton S. 2001.The role of USP in the assessment of microbiological quality of pharmaceuticals. Pharmarceutical Technology. 